\title{
Some properties of the $\mathrm{Ca}^{2+}$-stimulated ATPase of a rat liver microsomal fraction
}

\author{
Alan P. DAWSON* and Derek V. FULTON \\ School of Biological Sciences, University of East Anglia, Norwich NR4 7TJ, U.K.
}

(Received 10 August 1982/Accepted 25 October 1982)

\begin{abstract}
1. The heavy microsomal fraction from rat liver apparently has very little $\mathrm{Ca}^{2+}$ stimulated ATPase activity, although it has an active, ATP-driven $\mathrm{Ca}^{2+}$ accumulation system. 2. The addition of ionophore A23187 to the ATPase assay, to allow continuous $\mathrm{Ca}^{2+}$ recycling during the assay time, reveals the presence of a substantial $\mathrm{Ca}^{2+}$-stimulated ATPase with $V_{\max .} 160 \mathrm{nmol}$ of $\mathrm{P}_{\mathrm{i}} / 10 \mathrm{~min}$ per $\mathrm{mg}$ of protein and $K_{\mathrm{m}}$ for $\mathrm{Ca}^{2+} 0.19 \mu \mathrm{M}$. 3. The $\mathrm{Ca}^{2+}$-stimulated ATPase, but not the basal $\mathrm{Mg}^{2+}$-stimulated ATPase, is potently inhibited by orthovanadate. Both the $\mathrm{Ca}^{2+}$-stimulated ATPase and the vanadate inhibition are enhanced by the presence of $\mathrm{Mg}^{2+} .4 . \mathrm{Ca}^{2+}$-stimulated ATPase activity is not responsive to calmodulin or the calmodulin antagonist trifluoperazine.
\end{abstract}

The ATP-dependent $\mathrm{Ca}^{2+}$ accumulation system of rat liver microsomal fractions has been extensively studied in recent years because of its possible role in control of cytoplasmic $\mathrm{Ca}^{2+}$ concentration and involvement in hormonal control mechanisms (Moore et al., 1975; Bygrave, 1978; AndiaWaltenbaugh et al., 1980; Reinhart \& Bygrave, 1981; Dawson, 1982). However, relatively little work has been done on the $\mathrm{Ca}^{2+}$-stimulated ATPase activity of rat liver microsomes. Moore et al. (1975) and Andia-Waltenbaugh et al. (1980) reported the presence of a $\mathrm{Ca}^{2+}$-stimulated ATPase activity in this fraction, but in both cases the extra ATPase activity found in the presence of $\mathrm{Ca}^{2+}$ was very small compared with the basal $\mathrm{Mg}^{2+}$-stimulated ATPase, making detailed investigation difficult.

A possible explanation for the low levels of $\mathrm{Ca}^{2+}{ }^{2+}$ stimulated ATPase activity found in liver microsomes stems from the work of Bygrave (1978) and Dawson (1982) on the time course of $\mathrm{Ca}^{2+}$ accumulation into microsomal vesicles. In the absence of a precipitating anion such as oxalate, there is an initial rapid $\mathrm{Ca}^{2+}$ accumulation $\left(V_{0}=16 \mathrm{nmol}\right.$ of $\mathrm{Ca}^{2+} / \mathrm{min}$ per $\left.\mathrm{mg}\right)$, followed by a transition into a steady-state level of $\mathrm{Ca}^{2+}$ accumulation where the microsomal $\mathrm{Ca}^{2+}$ content remains constant at about $20 \mathrm{nmol} / \mathrm{mg}$. In this steady-state phase, the rate of ATP-driven $\mathrm{Ca}^{2+}$ accumulation is balanced by the rate of passive efflux of $\mathrm{Ca}^{2+}$ from the vesicles. However, the rate of passive efflux from microsomes under these conditions was found to be rather low (about $3 \mathrm{nmol}$ of

* To whom correspondence and reprint requests should be sent.

Vol. 210
$\mathrm{Ca}^{2+} /$ min per mg at $\mathrm{pH} 6.8$ and an internal $\mathrm{Ca}^{2+}$ load of $20 \mathrm{nmol} / \mathrm{mg}$; Dawson, 1982). This suggests that the rate of ATP-driven $\mathrm{Ca}^{2+}$ accumulation decreases from an initial rate of $16 \mathrm{nmol} / \mathrm{min}$ per $\mathrm{mg}$ to a steady-state turnover rate of about $3 \mathrm{nmol} / \mathrm{min}$ per $\mathrm{mg}$ as the internal $\mathrm{Ca}^{2+}$ concentration in the vesicles increases with, presumably, a corresponding decrease in the rate of ATP hydrolysis. Niggli et al. (1981) found that the activity of the red blood cell $\mathrm{Ca}^{2+} / \mathrm{Mg}^{2+}$-stimulated ATPase, after incorporation into liposomes, was greatly increased by the presence of ionophore A23187 to prevent the build-up of a $\mathrm{Ca}^{2+}$ concentration gradient. It seemed likely that the presence of the ionophore might also release the thermodynamic or kinetic restraint operating on the liver microsomal ATPase.

We report here that, in the presence of $\mathrm{A} 23187$, there is a readily detectable level of $\mathrm{Ca}^{2+}$-stimulated ATPase activity present in the rat liver heavy microsomal fraction (as defined by Reinhart \& Bygrave, 1981). The ATPase shows half-maximal activation by about $0.2 \mu \mathrm{M}$ free $\mathrm{Ca}^{2+}$ and its activity is enhanced by the presence of $\mathrm{Mg}^{2+}$. It is potently inhibited by vanadate but is apparently insensitive to calmodulin or the calmodulin antagonist trifluoperazine.

\section{Experimental}

Materials

${ }^{45} \mathrm{CaCl}_{2} \quad(650 \mathrm{Ci} / \mathrm{mol})$ was obtained from Amersham International, Amersham, Bucks., U.K. Hepes [4-(2-hydroxyethyl)-1-piperazine-ethanesulphonic acid] was from Hopkin and Williams and 
Ruthenium Red was from BDH, Poole, Dorset, U.K. Ruthenium Red was purified by the method of Fletcher et al. (1961). A23187 was from Calbiochem and calmodulin was purified from human red cells by the method of Muallem \& Karlish (1979). Trifluoperazine was from Sigma.

\section{Preparation of microsomes}

The heavy microsomal fraction was prepared from the livers of $200-250 \mathrm{~g}$ male albino Wistar rats by the method of Reinhart \& Bygrave (1981) and the protein concentration was determined as described previously (Dawson, 1982).

\section{ATPase assay}

The ATPase activity of the microsomal fraction was determined by measurement of $P_{1}$ release from ATP in the presence of oligomycin to inhibit any contaminating mitochondrial ATPase. The temperature was $37^{\circ} \mathrm{C}$. The incubation mixture contained, in a total volume of $1 \mathrm{ml}: 100 \mathrm{mM}-\mathrm{KCl}$; $20 \mathrm{~mm}$-Hepes/KOH buffer, $\mathrm{pH} 6.8 ; 5 \mathrm{mM}-\mathrm{MgCl}_{2}$, $1 \mu \mathrm{g}$ of oligomycin; $1 \mu \mathrm{g}$ of $\mathrm{A} 23187 ; \mathrm{CaCl}_{2}$ and EGTA, to give the required free $\mathrm{Ca}^{2+}$ concentration and about $0.7 \mathrm{mg}$ of microsomal protein. After pre-incubation at $37^{\circ} \mathrm{C}$ for $2 \mathrm{~min}$, the reaction was started by the addition of $1 \mathrm{~mm}$-ATP. After $10 \mathrm{~min}$ the assays were stopped by the addition of $0.5 \mathrm{ml}$ of $5 \%(w / v)$ trichloroacetic acid. Precipitated protein was removed by centrifugation and $\left[P_{1}\right]$ measured on a $1 \mathrm{ml}$ sample of the supernatant by the method of Fiske \& SubbaRow (1925). Total $\mathrm{Ca}^{2+}$ content of the assay mixtures was measured, after precipitation with trichloroacetic acid, by atomic-absorption spectrophotometry. Free $\left[\mathrm{Ca}^{2+}\right]$ was determined as described previously (Dawson, 1982).

\section{$\mathrm{Ca}^{2+}$-uptake assays}

These were done as described by Dawson (1982), except that the incubation medium was the same as that given for the assay of ATPase activity, with the addition of $1 \mu \mathrm{Ci}$ of ${ }^{45} \mathrm{Ca}^{2+}$ and $1 \mu \mathrm{M}$-Ruthenium Red and the omission of A23187.

\section{Results}

\section{Detection of a $\mathrm{Ca}^{2+}$-stimulated ATPase activity}

Fig. 1 shows the variation in microsomal ATPase activity with change in free $\mathrm{Ca}^{2+}$ concentration under several different experimental conditions. In agreement with the observations of AndiaWaltenbaugh et al. (1980), there is only a very small increment in ATPase activity on changing the free $\mathrm{Ca}^{2+}$ concentration from 0.01 to $1.0 \mu \mathrm{M}$ in the absence of oxalate and A23187. The addition of 5 mM-oxalate to the incubation medium causes an apparent increase in the basal $\mathrm{Mg}^{2+}$-stimulated ATPase activity but also reveals the presence of a $\mathrm{Ca}^{2+}$-stimulated ATPase activity, amounting to

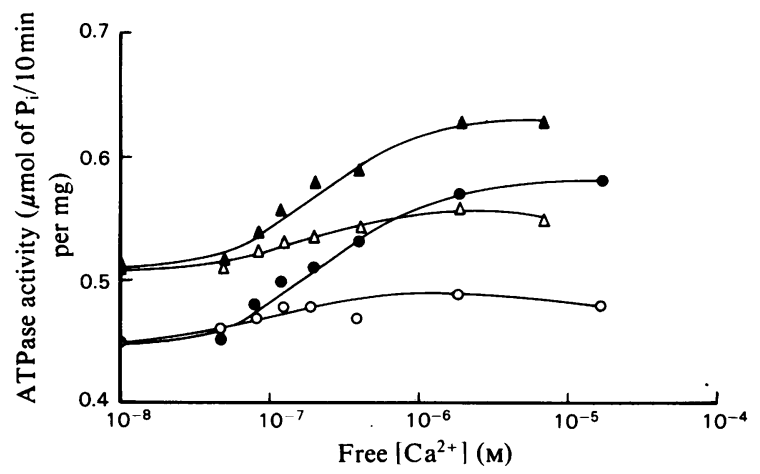

Fig. 1. Effects of oxalate and A23187 on ATPase activity ATPase activity was determined as described in the Experimental section with the following modifications to the basic medium: $O$, no A23187; - plus $1 \mu \mathrm{g}$ of $\mathrm{A} 23187 / \mathrm{ml} ; \Delta$, no $\mathrm{A} 23187$, plus $5 \mathrm{~mm}$-ammonium oxalate; $\Delta$, plus $1 \mu \mathrm{g}$ of $\mathrm{A} 23187 /$ $\mathrm{ml}$ and $5 \mathrm{~mm}$-ammonium oxalate. The protein concentration was $0.9 \mathrm{mg} / \mathrm{ml}$. For the first datum point on each line, the total $\mathrm{Ca}^{2+}$ concentration was $18 \mu \mathrm{M}$ and EGTA was $1 \mathrm{mM}$. For the remaining points, total $\mathrm{Ca}^{2+}$ was $81 \mu \mathrm{M}$ and EGTA was (in mM) $1,0.62,0.44,0.31,0.19,0.1,0.06$, to give the free $\mathrm{Ca}^{2+}$ concentrations shown. The method for calculating free $\mathrm{Ca}^{2+}$ concentrations allows for formation of $\mathrm{a} \mathrm{Ca}^{2+}$-oxalate complex.

about $50 \mathrm{nmol}$ of $\mathrm{P}_{1} / 10 \mathrm{~min}$ per $\mathrm{mg}$, when the free $\left[\mathrm{Ca}^{2+}\right]$ is increased from 0.01 to $1.0 \mu \mathrm{M}$. The presence of oxalate allows microsomal $\mathrm{Ca}^{2+}$ accumulation to continue throughout the assay time, although at a lower rate than observed during the first 90s of the progress curve (Bygrave, 1978; Dawson, 1982). The effect of oxalate on the basal $\mathrm{Mg}^{2+}$-stimulated ATPase is probably due to chelation of $\mathrm{Mg}^{2+}$ by oxalate. Increasing the $\mathrm{Mg}^{2+}$ concentration in the assay medium from 2 to $5 \mathrm{mM}$ in the absence of oxalate causes a small inhibition of the basal ATPase activity (results not shown). The addition of $5 \mathrm{~mm}$-oxalate to the medium decreases the free $\mathrm{Mg}^{2+}$ concentration from $4 \mathrm{mM}$ to $2 \mathrm{mM}$ and will therefore relieve the inhibition by high $\mathrm{Mg}^{2+}$.

The addition of $\mathrm{A} 23187$, in either the presence or the absence of oxalate, reveals the presence of a substantial $\mathrm{Ca}^{2+}$-stimulated ATPase activity. In the experiment shown in Fig. 1, this amounts to about $140 \mathrm{nmol}$ of $P_{1} / 10 \mathrm{~min}$ per $\mathrm{mg}$ of protein. The increment in ATPase activity on increasing the free $\mathrm{Ca}^{2+}$ concentration from $0.01 \mu \mathrm{M}$ to $1.0 \mu \mathrm{M}$ is the same, irrespective of the presence or absence of oxalate, although, as discussed above, the basal $\mathrm{Mg}^{2+}$-stimulated ATPase activity is different in the two cases. For eight different microsome preparations, the ATPase activities were as follows (means \pm S.E.M.): $\mathbf{M g}^{2+}$-stimulated ATPase (at 


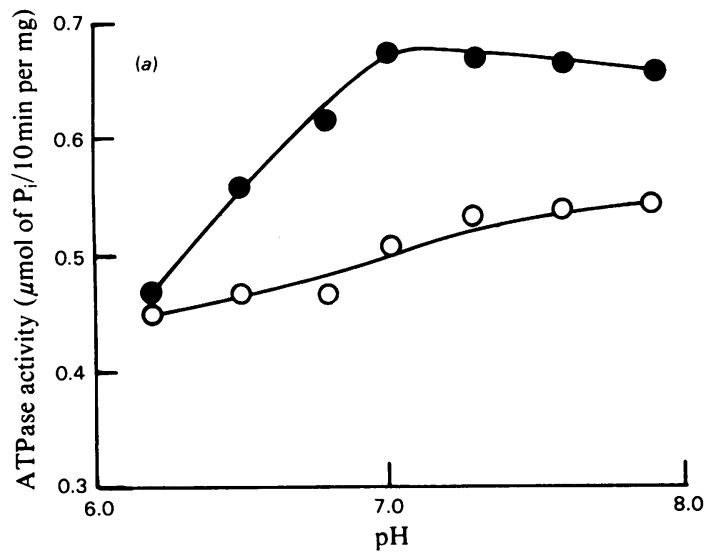

Fig. 2 shows the $\mathrm{pH}$ profile of the $\mathrm{Ca}^{2+}$-stimulated ATPase activity. In agreement with the data for $\mathrm{pH}$-dependence of $\mathrm{Ca}^{2+}$-accumulation (Dawson, 1982), the optimum $\mathrm{pH}$ is about 7.0 , with a steep decline in activity below pH 6.8 but a more gradual decline on the alkaline side. In contrast, the $\mathrm{Mg}^{2+}$-stimulated ATPase at low free $\left[\mathrm{Ca}^{2+}\right]$ shows a very weak $\mathrm{pH}$-dependence over this range.

\section{Effects of vanadate and $\mathrm{Mg}^{2+}$ on ATPase activity}

Orthovanadate has been found to be a potent inhibitor of various ATPase systems, including the $\left(\mathrm{Na}^{+}+\mathrm{K}^{+}\right)$-dependent ATPase (Josephson \& Cantley, 1977) and the $\mathrm{Ca}^{2+}$-translocating. ATPases of sarcoplasmic reticulum (Wang et al., 1979), red blood cell membranes (Bond \& Hudgins, 1980; Niggli et al., 1981), heart sarcolemma (Caroni \& Carafoli, 1981) and intestinal smooth-muscle microsomes (Wibo et al., 1981). Fig. 3 shows the effect of orthovanadate, in the presence of $5 \mathrm{mM}-\mathrm{Mg}^{2+}$, on liver microsomal ATPase activity in the presence and absence of $\mathrm{Ca}^{2+}$. In the absence of $\mathrm{Ca}^{2+}$ $(<0.01 \mu \mathrm{M}$ free) there is very little effect of vanadate on ATPase activity. However, the $\mathrm{Ca}^{2+}$-stimulated activity is very potently inhibited by vanadate, addition of $0.5 \mu \mathrm{M}$-vanadate causing $50 \%$ inhibition. Fig. 3 also shows that under similar conditions, but in the absence of $\mathrm{A} 23187$, the initial rate of $\mathrm{Ca}^{2+}$ accumulation is inhibited by vanadate to the same extent as ATPase activity. $\mathrm{Ca}^{2+}$ accumulation measured over a longer time period is less affected by vanadate, suggesting that a high intravesicular $\mathrm{Ca}^{2+}$ concentration reverses the inhibition.

As in the case of the $\mathrm{Ca}^{2+} / \mathrm{Mg}^{2+}$-stimulated ATPase of red blood cell membranes (Bond \& Hudgins, 1980; Niggli et al., 1981) and sarcoplasmic reticulum (Pick, 1982), inhibition by vanadate is dependent on the presence of $\mathrm{Mg}^{2+}$ (Fig. 4), maximal inhibition being obtained at about $3 \mathrm{mM}-\mathrm{Mg}^{2+}$. Fig. 4 also shows that added $\mathbf{M g}^{2+}$ enhances the activity not only of basal ATPase, observed at low free $\mathrm{Ca}^{2+}$ concentrations, but also of the $\mathrm{Ca}^{2+}$-stimulated ATPase activity. The dependence of $\mathrm{Ca}^{2+}$-stimulated ATPase activity on $\mathrm{Mg}^{2+}$ concentration appears to be very similar to that for the basal ATPase.

\section{Effects of calmodulin and trifluoperazine}

$\left.0.01 \mu \mathrm{M}-\mathrm{Ca}^{2+}\right), 0.45 \pm 0.02 \mu \mathrm{mol}$ of $\mathrm{P}_{1} / 10 \mathrm{~min}$ per $\mathrm{mg} ; \mathrm{Mg}^{2+} / \mathrm{Ca}^{2+}$-stimulated ATPase (at $1.0 \mu \mathrm{M}-\mathrm{Ca}^{2+}$ ) $0.61 \pm 0.03 \mu \mathrm{mol}$ of $P_{1} / 10 \mathrm{~min}$ per $\mathrm{mg}$; the paired difference for the eight preparations, giving the $\mathrm{Ca}^{2+}$-stimulated ATPase activity, was $0.16 \pm$ $0.01 \mu \mathrm{mol}$ of $\mathrm{P}_{\mathrm{l}} / 10 \mathrm{~min}$ per $\mathrm{mg}$. The free $\mathrm{Ca}^{2+}$ concentration giving half-maximal stimulation of the ATPase was $0.19 \pm 0.04 \mu \mathrm{M} \quad(n=4)$. The comparative data for $\mathrm{Ca}^{2+}$ accumulation reported previously (Dawson, 1982) are $V_{\max .} 16 \mathrm{nmol} / \mathrm{min}$ per mg and $K_{\mathrm{m}} 0.2 \mu \mathrm{M}$ for free $\mathrm{Ca}^{2+}$.

Calmodulin has been shown to have a direct effect on the activity of $\mathrm{Ca}^{2+}$-transporting ATPase systems from a variety of sources, such as red blood cells (Gopinath \& Vicenzi, 1977; Jarrett \& Penniston, 1977), heart sarcolemma (Caroni \& Carafoli, 1981) and parotid endoplasmic reticulum (Kanasuntheram $\&$ Teo, 1982). In view of the possibility of liver endoplasmic reticulum playing a part in controlling cytoplasmic $\mathrm{Ca}^{2+}$ concentration (Berthon et al., 1981 ) it was important to investigate the effects of calmodulin on the liver microsomal $\mathrm{Ca}^{2+}$-stimulated

Vol. 210 

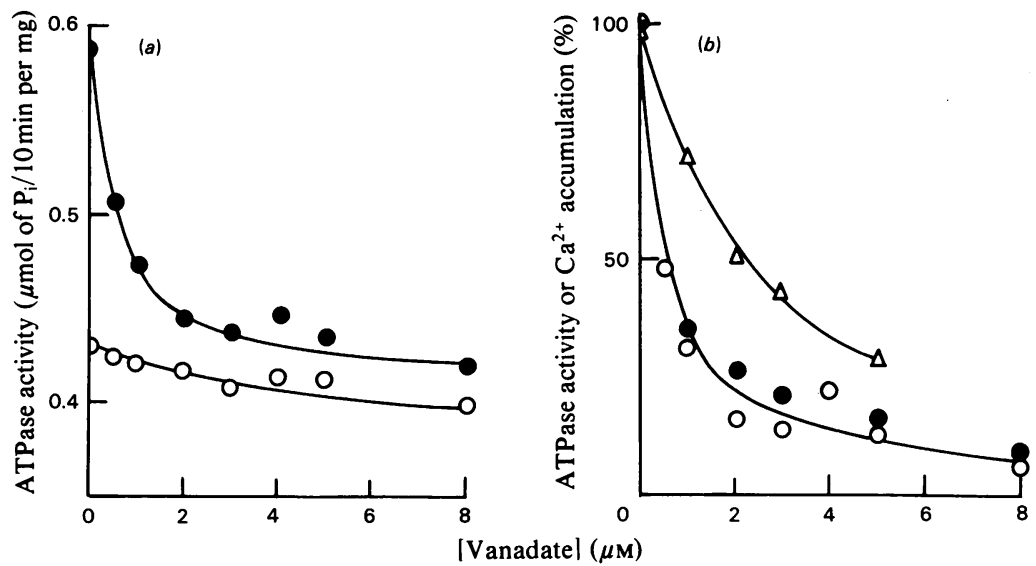

Fig. 3. Effects of vanadate on ATPase activity and $\mathrm{Ca}^{2+}$ accumulation

The ATPase assay and $\mathrm{Ca}^{2+}$ accumulation measurements were as described in the Experimental section, except that the microsomes were pre-incubated at a concentration of $0.9 \mathrm{mg} / \mathrm{ml}$ in the assay medium with the required vanadate concentration for $12 \mathrm{~min}$ before addition of ATP. (a) ATPase activity: O, plus $1 \mathrm{mM}$-EGTA and $28 \mu \mathrm{M}-\mathrm{Ca}^{2+}$ (free $\left.\left[\mathrm{Ca}^{2+}\right]=16 \mathrm{nM}\right) ; \bullet$, plus $0.1 \mathrm{mM}$-EGTA and $77 \mu \mathrm{M}-\mathrm{Ca}^{2+}\left(\right.$ free $\left.\left[\mathrm{Ca}^{2+}\right]=1.76 \mu \mathrm{M}\right)$. (b) Comparative effects on ATPase and $\mathrm{Ca}^{2+}$ accumulation. $O$, Percentage activity of $\mathrm{Ca}^{2+}$-stimulated ATPase; accumulation measured $20 \mathrm{~s}$ after initiation of uptake with ATP; $\Delta$, percentage activity of $\mathrm{Ca}^{2+}$ accumulation measured $45 \mathrm{~s}$ after initiation of uptake with ATP. For the uptake measurements, conditions were as for $(a)$, with a free $\mathrm{Ca}^{2+}$ concentration of $1.76 \mu \mathrm{M}$, with the omission of $\mathrm{A} 23187$ but with the addition of $1 \mu \mathrm{Ci}$ of ${ }^{45} \mathrm{Ca}^{2+} / \mathrm{ml}$ and $1 \mu \mathrm{M}$-Ruthenium Red.

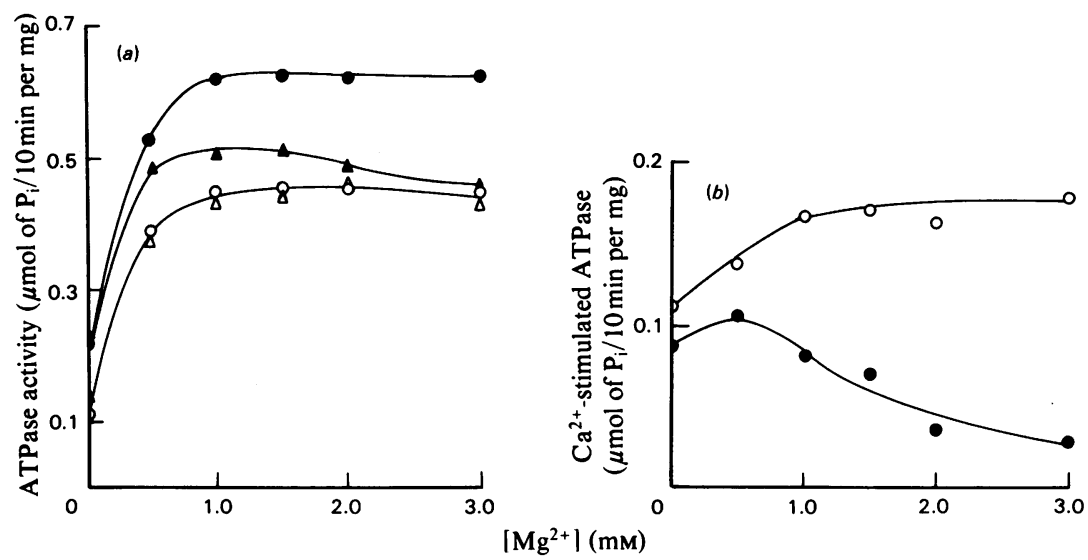

Fig. 4. Dependence of ATPase activity and vanadate inhibition on $\mathbf{M g}^{2+}$ concentration

(a) Total ATPase activity. Microsomes $(0.7 \mathrm{mg} / \mathrm{ml})$ were pre-incubated for $10 \mathrm{~min}$ in the presence $(\Delta$ and $\Delta)$ or absence $(\mathrm{O}$ and $\Theta$ ) of $2 \mu \mathrm{M}$-orthovanadate before ATP addition. The ATPase assay medium was the same as that given in the Experimental section, with various $\mathrm{Mg}^{2+}$ concentrations and $\mathrm{Ca}^{2+}$ concentrations of: $\mathrm{O}$ and $\Delta, 0.008 \mu \mathrm{M}$ (1 mM-EGTA, $14.5 \mu \mathrm{M}-\mathrm{Ca}^{2+}$ total); $\odot$ and $\triangle, 0.84 \mu \mathrm{M}\left(0.1 \mathrm{mM}-\mathrm{EGTA}, 65 \mu \mathrm{M}-\mathrm{Ca}^{2+}\right.$ total) at no added $\mathrm{Mg}^{2+}$, changing to $0.96 \mu \mathrm{M}-\mathrm{Ca}^{2+}$ at $3 \mathrm{mM}-\mathrm{Mg}^{2+}$. (b) $\mathrm{Ca}^{2+}$-stimulated ATPase activity: $O$, no vanadate present; $\bullet$, plus $2 \mu \mathrm{M}$-vanadate. The points $(O)$ are derived from the data points $(\bullet$ minus $O)$ in $(a)$, and the points $(O)$ are derived from the data points $(\Delta$ minus $\Delta)$ in $(a)$.

ATPase. Pre-incubation of microsomes with $5 \mu \mathrm{g}$ of human red cell calmodulin $/ \mathrm{ml}$ has no effect on the $\mathrm{Ca}^{2+}$-stimulated ATPase activity over the $\mathrm{Ca}^{2+}$ concentration range used in Fig. 1. However, it has been reported that rat liver microsomes contain endogenous calmodulin (Carafoli et al., 1980). We have found that after boiling the microsomes used in this study for $10 \mathrm{~min}$ at $5 \mathrm{mg}$ of protein $/ \mathrm{ml}$ in $5 \mathrm{mM}$ - 
Hepes/KOH, pH 6.8, the supernatant contains a calmodulin-like activity that is equivalent in its effect on the red-cell $\mathrm{Ca}^{2+}$-stimulated ATPase to about $1 \mu \mathrm{g}$ of calmodulin $/ \mathrm{ml}$ of supernatant. To remove endogenous calmodulin a procedure based on that described by Caroni \& Carafoli (1981) was used. The microsomes were extracted with 1 mM-EGTA/ $5 \mathrm{~mm}$-Hepes/KOH (pH 6.8), followed by centrifugation and resuspension in $1 \mathrm{M}-\mathrm{NaCl} / 1 \mathrm{mM}-\mathrm{EGTA} /$ $5 \mathrm{mM}-\mathrm{Hepes} / \mathrm{KOH}$ ( $\mathrm{pH} 6.8$ ). After centrifugation, the microsomes were put through the same two extraction media again and were finally washed and resuspended in $250 \mathrm{~mm}$-sucrose $/ 10 \mathrm{mM}-\mathrm{KCl} 1 \mathrm{~mm}$ dithiothreitol $5 \mathrm{~mm}-\mathrm{Hepes} / \mathrm{KOH} \quad(\mathrm{pH}$ 6.8). This treatment decreased the endogenous calmodulin-like activity by $>70 \%$ compared with the original microsomes. The specific activity of the basal ATPase $\left(\mathrm{Ca}^{2+}=0.01 \mu \mathrm{M}\right)$ is increased approx. 2fold by the washing procedure to $0.85 \mu \mathrm{mol}$ of $P_{i} / 10$ min per $\mathrm{mg}$, presumably by removal of extrinsic membrane proteins. However, the $\mathrm{Ca}^{2+}$ stimulated component of the ATPase is very similar in size to that in untreated microsomes $(0.15 \mu \mathrm{mol}$ of $P_{i} / 10 \mathrm{~min}$ per $\mathrm{mg}$ ) indicating that, relative to the basal ATPase, approximately half of the $\mathrm{Ca}^{2+}$ stimulated activity has been lost. Even though the extraction apparently causes an inactivation of the $\mathrm{Ca}^{2+}$-stimulated ATPase, addition of $5 \mu \mathrm{g}$ of calmodulin $/ \mathrm{ml}$ has essentially no effect on its activity, suggesting that the loss of $\mathrm{Ca}^{2+}$-stimulation is not connected with the removal of endogenous calmodulin. Furthermore, the calmodulin antagonist trifluoperazine, at concentrations up to $100 \mu \mathrm{M}$, has no effect on the $\mathrm{Ca}^{2+}$-stimulated ATPase activity of non-extracted microsomes over the $\mathrm{Ca}^{2+}$ concentration range used in Fig. 1. Trifluoperazine causes a small decrease in the ATPase activity in the absence of $\mathrm{Ca}^{2+}$, but at the concentrations of inhibitor used this is likely to be a non-specific effect.

\section{Discussion}

The ATPase activity of rat liver microsomes appears to contain at least two components. There is an $\mathrm{Mg}^{2+}$-stimulated ATPase with a specific activity of $0.45 \mu \mathrm{mol}$ of $P_{i} / 10 \mathrm{~min}$ per $\mathrm{mg}$ of protein and an additional, smaller, $\mathrm{Ca}^{2+}$-stimulated activity with a specific activity of $0.16 \mu \mathrm{mol}$ of $\mathrm{P}_{\mathrm{i}} / 10 \mathrm{~min}$ per $\mathrm{mg}$ of protein, observable in the presence of A23187 to prevent the development of a $\mathrm{Ca}^{2+}$ concentration gradient. Although both activities have similar dependence on $\mathrm{Mg}^{2+}$ concentration, they appear to reflect the presence of two different enzymes, since the $\mathrm{pH}$ profiles of the two are different and the $\mathrm{Ca}^{2+}$-stimulated activity is potently inhibited by vanadate, whereas the $\mathrm{Ca}^{2+}$-independent activity is not. Although the function of the $\mathrm{Ca}^{2+}$-independent ATPase is obscure, the $\mathrm{Ca}^{2+}$-stimulated ATPase seems to be involved in $\mathrm{Ca}^{2+}$ pumping across the microsomal membrane. The pH-dependence, inhibition by vanadate and $K_{\mathrm{m}}$ for $\mathrm{Ca}^{2+}$ of the ATPase are all very similar to the equivalent parameters measured for $\mathrm{Ca}^{2+}$-uptake by microsomes (Dawson, 1982). The $V_{\max }$ of $160 \mathrm{nmol}$ of $\mathrm{P}_{\mathrm{i}} / 10$ min per $\mathrm{mg}$, taken with the $V_{\text {max }}$. for $\mathrm{Ca}^{2+}$. uptake $\left(16 \mathrm{nmol}\right.$ of $\mathrm{Ca}^{2+} / \mathrm{min}$ per $\left.\mathrm{mg}\right)$, suggests a stoichiometry of $1 \mathrm{Ca}^{2+} / \mathrm{ATP}$, similar to that reported by Niggli et al. (1981) for the erythrocyte membrane $\mathrm{Ca}^{2+} / \mathrm{Mg}^{2+}$-stimulated ATPase.

Apart from its insensitivity to calmodulin, other properties of the enzyme, such as the potency of vanadate inhibition, $\mathrm{pH}$ profile and $K_{\mathrm{m}}$ for $\mathrm{Ca}^{2+}$ are very similar to the equivalent properties, tabulated by Caroni \& Carafoli (1981), for the heart sarcolemma and erythrocyte plasma-membrane $\mathrm{Ca}^{2+}$ / $\mathrm{Mg}^{2+}$-stimulated ATPases. In contrast, $\mathrm{Ca}^{2+} / \mathrm{Mg}^{2+}$ stimulated ATPases derived from sarcoplasmic reticulum or analogous structures show a higher $K_{\mathrm{i}}$ for vanadate and a somewhat higher $K_{\mathrm{m}}$ for $\mathrm{Ca}^{2+}$ (Caroni \& Carafoli, 1981; Wibo et al., 1981). To this extent it would thus appear possible that the liver microsomal $\mathrm{Ca}^{2+}$-transport system was derived from plasma-membrane fragments. A $\mathrm{Ca}^{2+}$ stimulated ATPase has been detected in liver plasma membranes (Lotersztajn et al., 1981; Iwasa et al., 1982) but in native membranes this is only observable in the absence of added $\mathrm{Mg}^{2+}$. The purified $\mathrm{Ca}^{2+}$-stimulated ATPase from plasma membranes was found to be $\mathrm{Mg}^{2+}$-dependent but had a very high affinity for $\mathrm{Ca}^{2+}\left(K_{0.5}=13 \mathrm{nM}-\mathrm{Ca}^{2+}\right.$; Lotersztajn et al., 1981) compared with the value reported here for microsomes. The plasma-membrane $\mathrm{Ca}^{2+}$ stimulated ATPase studied by Iwasa et al. (1982) also showed a rather higher affinity for $\mathrm{Ca}^{2+}$, was apparently $\mathrm{Mg}^{2+}$-independent and was not inhibited by vanadate (albeit in the absence of added $\mathrm{Mg}^{2+}$ ). The $\mathrm{Ca}^{2+}$-stimulated ATPase of rat liver microsomes appears therefore to differ in some important respects from the rat liver plasma-membrane enzyme and hence is likely to originate from a different, presumably intracellular, membrane type.

\section{References}

Andia-Waltenbaugh, A. M., Lam, A., Hummel, L. \& Friedman, N. (1980) Biochim. Biophys. Acta 630, 165-175

Berthon, B., Poggioli, J., Capiod, T. \& Claret, M. (1981) Biochem. J. 200, 177-180

Bond, G. H. \& Hudgins, P. M. (1980) Biochim. Biophys. Acta 600, 781-790

Bygrave, F. L. (1978) Biochem. J. 170, 87-91

Carafoli, E., Niggli, V., Malmström, K. \& Caroni, P. (1980) Ann. N. Y. Acad. Sci. 356, 258-278

Caroni, P. \& Carafoli, E. (1981) J. Biol. Chem. 256, $3263-3270$

Dawson, A. P. (1982) Biochem. J. 206, 73-79 
Fiske, C. H. \& SubbaRow, Y. (1925) J. Biol. Chem. 66 , 375-400

Fletcher, J. M., Greenfield, B. F., Hardy, C. J., Scargill, D. \& Woodhead, J. L. (1961) J. Chem. Soc. 20002006

Gopinath, R. M. \& Vicenzi, F. F. (1977) Biochem. Biophys. Res. Commun. 77, 1203-1209

Iwasa, Y., Iwasa, T., Higashi, K., Matsui, K. \& Miyamoto, E. (1982) Biochem. Biophys. Res. Commun. 105, 488-494

Jarrett, H. W. \& Penniston, J. T. (1977) Biochem. Biophys. Res. Commun. 77, 1210-1216

Josephson, L. \& Cantley, L. C. (1977) Biochemistry 16, $4572-4578$

Kanagasuntheram, P. \& Teo, T. S. (1982) FEBS Lett. 141, 233-236
Lotersztajn, S., Hanoune, J. \& Pecker, F. (1981) J. Biol. Chem. 256, 11209-11215

Moore, L., Chen, T., Knapp, H. R. \& Landon, E. J. (1975) J. Biol. Chem. 250, 4562-4568

Muallem, S. \& Karlish, S. J. D. (1979) FEBS Lett. 107. 209-212

Niggli, V., Adunyah, E. S., Penniston, J. T. \& Carafoli, E. (1981) J. Biol. Chem. 256, 395-401

Pick, U. (1982) J. Biol. Chem. 257, 6111-6119

Reinhart, P.H. \& Bygrave, F. L. (1981) Biochem. J. 194. 541-549

Wang, T., Tsai, L.-I., Solaro, R. J., Grassi de Gende, A. O. \& Schwartz, A. (1979) Biochem. Biophys. Res. Commun. 91, 356-361

Wibo, M., Morel, N. \& Godfraind, T. (1981) Biochim. Biophys. Acta 649, 651-660 